\title{
Prevention of overweight and obesity in children and youth: a systematic review and meta-analysis
}

\author{
Leslea Peirson PhD, Donna Fitzpatrick-Lewis MSW, Katherine Morrison MD, Donna Ciliska PhD, \\ Meghan Kenny MA, Muhammad Usman Ali MD, Parminder Raina PhD
}

\section{Abstract}

Background: One-third of Canadian children are overweight or obese. This problem carries considerable concern for negative impacts on current and future health. Promoting healthy growth and development is critical. This review synthesized evidence on the effectiveness of behavioural interventions for preventing overweight and obesity in children and adolescents.

Methods: We updated the search of a previous Cochrane review. Five databases were searched up to August 2013. Randomized trials of primary care-relevant behavioural (diet, exercise and lifestyle) interventions for preventing overweight and obesity in healthy normalor mixed-weight children or youth aged 0-18 years were included if 12-week postbaseline data were provided for body mass index (BMI), BMI Z-score, or prevalence of overweight or obesity. Any study reporting harms was included. Meta-analyses were performed if possible. Features of interventions showing significant benefits were examined.

Results: Ninety studies were included, all with mixed-weight populations. Compared with controls, interventions showed a small but significant effect on BMI and BMI Z-score (standardized mean difference $-0.07,95 \%$ confidence interval $[\mathrm{Cl}]-0.10$ to $-0.03, l^{2}=74 \%$ ), a reduction in $\mathrm{BMI}$ (mean difference $-0.09 \mathrm{~kg} / \mathrm{m}^{2}, 95 \% \mathrm{Cl}-0.16$ to $-0.03, l^{2}=76 \%$ ) and a reduced prevalence of overweight and obesity (risk ratio $\left[\mathrm{RR}\right.$ ]; $\mathrm{RR}_{\text {intervention }}-\mathrm{RR}_{\text {control }} 0.94,95 \% \mathrm{Cl} 0.89$ to $0.99, I^{2}=0 \%$; number needed to treat $51,95 \% \mathrm{Cl} 29$ to 289 ). Little evidence was available on harms. There was variability across efficacious interventions, although many of the interventions were short-term, involved school-aged children and were delivered in educational settings.

Interpretation: Behavioural prevention interventions are associated with small improvements in weight outcomes in mixed-weight populations of children and adolescents. No intervention strategy consistently produced benefits. Registration: PROSPERO no. CRD42012002754

hildhood and adolescence are characterized by substantial physical growth and development. Weight gain is expected and desirable as children get taller and older. However, children and teens who are overweight or obese face social, emotional and physical challenges, and if excess weight is retained into adulthood, there is a greater risk for obesity-related health problems. ${ }^{1-5}$ For those aged 5-19 years, the World Health Organization defines overweight as $>85$ th centile and obesity as $>97$ th centile; for children aged 2-5 years the cut-offs are more conservative (overweight $>97$ th centile, obesity $>99.9$ th centile). ${ }^{6}$ Using these standards, almost one-third (31.5\%) of the elementary and secondary school-aged children and youth in Canada are overweight or obese. This situation calls for preventive efforts to promote healthy weight in childhood and adolescence, and also as a means to build a strong foundation for maintaining healthy weight in adulthood.
Treatment of obesity in children and adolescents is an active area of research, and a number of systematic reviews have been published recently. ${ }^{7-13}$ In addition, reviews have been published about the prevention of obesity in children, ${ }^{14}$ including community-, ${ }^{15}$ home- ${ }^{16}$ and school-based ${ }^{17-19}$ interventions, and using diverse approaches such as educational programs,${ }^{20}$ reduction of screen time,${ }^{21}$ and behavioural strategies associated with diet and physical activity. ${ }^{22}$ This review provides a synthesis of the effectiveness of interventions for

Competing interests: See end of article.

This article has been peer reviewed.

Correspondence to: Leslea Peirson, peirson@mcmaster.ca; Parminder Raina, praina@mcmaster.ca

CMAJ Open 2015.DOI:10.9778/cmajo.20140053 
the prevention of childhood obesity that are feasible for use in primary care or for referral in the community and examines the features of efficacious interventions.

\section{Methods}

\section{Search strategy}

A recent high-quality (11/11 AMSTAR rating) ${ }^{23}$ Cochrane Review examined interventions for preventing obesity in children. ${ }^{17}$ Cochrane Reviews are often considered gold standard, and, upon evaluation, it was determined that their search strategy addressed our key questions. For these reasons and to avoid duplication, our protocol was designed to update their search. We searched Embase, MEDLINE, Cochrane Central Register of Controlled Trials, PsycINFO and CINAHL from Jan.1, 2010 (just prior to the date of the last Cochrane search) to Aug. 1, 2013. The Medline strategy appears in Appendix 1 (available at www.cmajopen.ca/content/3/1/E23/suppl/DC1). The Cochrane group also provided a list of citations being considered for their next update. Reference lists of included studies and pertinent reviews were searched for studies not captured by our search. A focused grey literature search of Canadian sources was undertaken for recent reports on obesity in Canada.

\section{Population, intervention, comparator, outcome and setting statement}

The PICOS (population, intervention, comparator, outcome, setting) framework was (P) normal- or mixed-weight children

Box 1: Description of population, intervention, comparator, outcomes and setting

Population

- Children and youth aged 0-18 years

- Normal-weight or mixed-weight populations

Interventions

- Behavioural (diet, exercise, diet plus exercise or lifestyle) interventions for prevention of weight gain

Comparator

- Intervention effectiveness: no intervention, usual care or minimal intervention (e.g., newsletter or single information session on healthy living)

- Intervention harms: any type of comparison group or no comparison group

Outcomes

- Intervention effectiveness: change in body mass index (BMI) and BMI z-score, change in prevalence of overweight or obesity

- Intervention harms: disordered eating, psychological distress (e.g., anxiety), deficits in micronutrients, abnormal growth trajectory and growth restriction

Settings

- Generalizable to Canadian primary care or feasible for use in or referral from primary care; interventions should be initiated through (or feasible within) a primary care setting and (could be) delivered by a health care professional (e.g., physician, psychologist, nurse or dietician) and youth aged 0-18 years; (I) behavioural interventions for prevention of weight gain; (C) no intervention, usual practice or minimal component; $(\mathrm{O})$ change in body mass index (BMI), BMI z-score or prevalence of overweight and obesity, and harms of interventions; and (S) generalizable to primary care in Canada. Additional details are provided in Box 1.

\section{Inclusion and exclusion criteria}

The inclusion and exclusion criteria for this review are provided in Box 2.

\section{Study selection, quality assessment and data abstraction}

Titles and abstracts were reviewed independently in duplicate. Citations marked for inclusion by either team member went on to full-text screening, which was also done independently in duplicate. Randomized trials were assessed using the Cochrane Collaborations's tool for risk-of-bias assessment. ${ }^{24}$ Overall strength of the evidence (assessed as high, moderate, low or very low quality) was determined using the Grading of Recommendations Assessment, Development and Evaluation framework (GRADEpro [computer program], version 3.2 for Windows; available at www.ims.cochrane.org /revman/gradepro)..$^{25}$ Interrater disagreements were resolved through discussion. One team member completed full abstraction and a second verified all extractions. All data were re-verified before analysis.

\section{Box 2: Inclusion and exclusion criteria}

Studies were included if they met the following criteria:

- Behavioural (diet, exercise, social support or lifestyle strategies alone or in combination) trial of weight gain prevention

- Minimum 12-week intervention involving children or youth aged 0-18 years who were normal or mixed weight

- Randomized controlled trial with a no intervention, usual practice or minimal component (e.g., single newsletter or information session on general health) comparison group

- Reported data for one or more specified weight outcomes (i.e., change in BMI, BMI z-score, or prevalence of overweight or obesity)

- Reported data for weight outcomes of interest at least 12 weeks postbaseline assessment

- No restrictions on study design, comparison group, reporting of weight outcomes or timing of assessment were applied to studies that reported data for harms of interventions

- Results were published in English or French

Studies were excluded for the following reasons:

- Intervention involved surgical procedures, medications or was intended to treat obesity

- Intervention targeted only obese children and youth (treatment of obesity), involved a population with serious illness or comorbidity, or pregnant adolescents

- Intervention was conducted in an in-patient hospital setting (excluded as representing a level of intervention not feasible for prevention)

- Results were published in a language other than English or French 


\section{Data analysis}

For meta-analyses, means and standard deviations (SD) were used for continuous outcomes (i.e., BMI and BMI z-score), and counts data were used for the binary outcome (i.e., prevalence). Whenever possible, immediate posttreatment data were used, otherwise the data point closest to the end of the intervention was selected. If studies reported results for boys and for girls, we entered these data separately into the metaanalyses. For studies with more than one intervention arm, we combined data from similar groups to do a pair-wise comparison with the control group. ${ }^{24}$ If groups were substantially different, we included the data for each arm compared with the control group but split the sample size for the control to avoid a unit-of-analysis error and double counting. ${ }^{24}$ Cochran's Q ( $\alpha=0.05)$ and $I^{2}(\geq 75 \%=$ substantial heterogeneity) statistics were used to quantify statistical heterogeneity between studies. Statistical analyses were performed using Review Manager version 5.3, STATA version 12 and GRADEpro.

Standardized mean difference (SMD) was chosen as a summary measure of effect to allow us to combine data for BMI and BMI z-score in a single meta-analysis; if a study reported both outcomes, we used the nonstandardized data. This strategy, which is consistent with the approach taken in 2 major reviews on this topic, ${ }^{13,17}$ increases the pool of studies, thereby increasing the power to detect a difference in weight change between groups. A second meta-analysis included only studies that reported change in BMI and used mean difference (MD) as the summary measure of effect. The DerSimonian and Laird random-effects model with inverse variance ${ }^{26}$ was used to generate SMDs for BMI and BMI z-score $(<0.2=$ very small effect, $\geq 0.2$ and $<0.5=$ small effect, $<0.5$ and $<0.8=$ medium effect; $>0.8=$ large effect $)^{27}$ and MD for BMI alone. For the outcome of BMI and BMI z-score, we did sensitivity analyses based on age groups (0-5, 6-12 and 13-18 yr), intervention type (diet, exercise, diet plus exercise and lifestyle), intervention setting (noneducational, educational only and educational plus other) intervention duration $(\leq 12 \mathrm{mo}$ and $>12 \mathrm{mo}$ ), sex and study risk of bias rating (low, unclear and

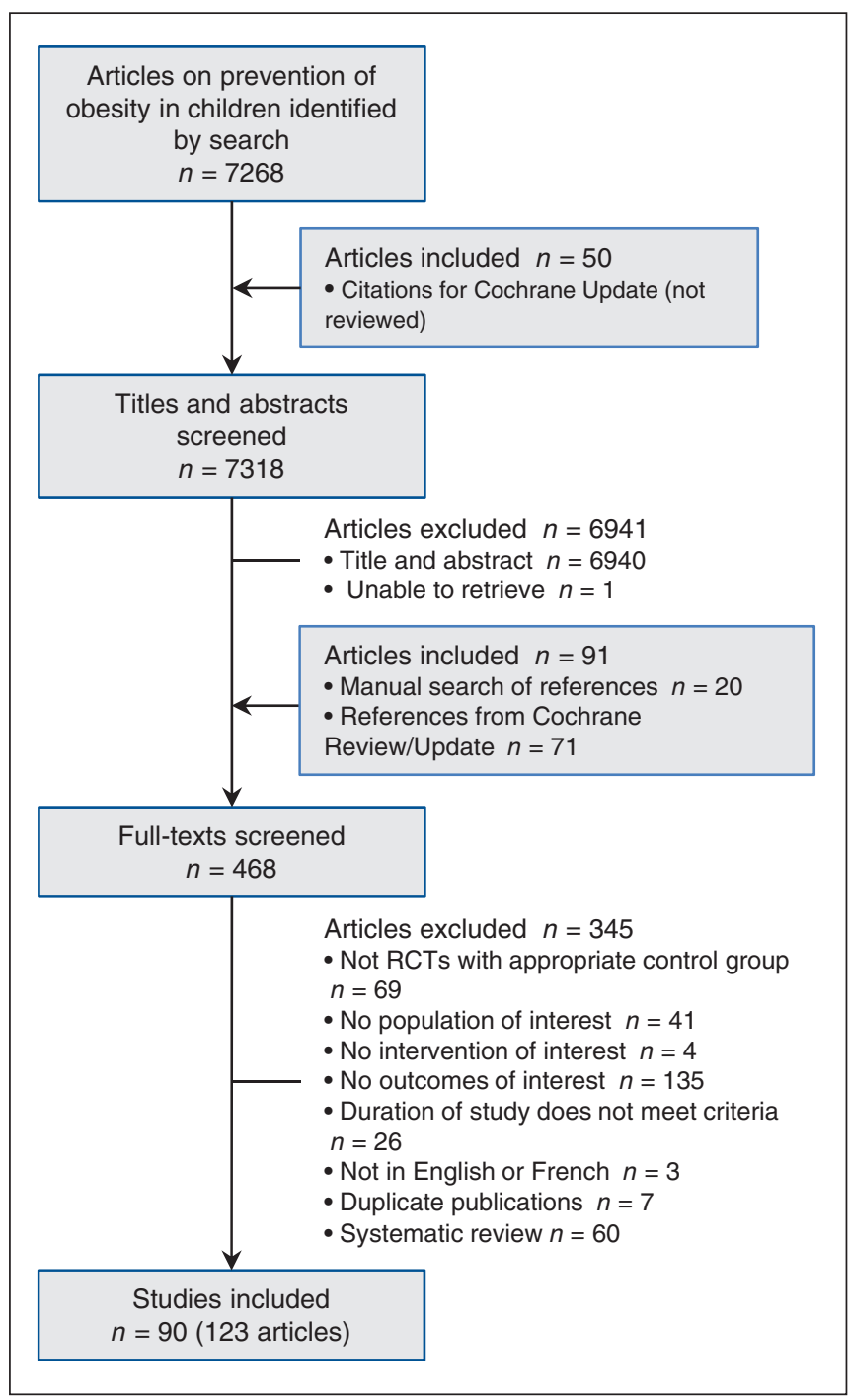

Figure 1: Selection of studies evaluating interventions to prevent overweight and obesity in children and youth. RCT = randomized controlled trial.

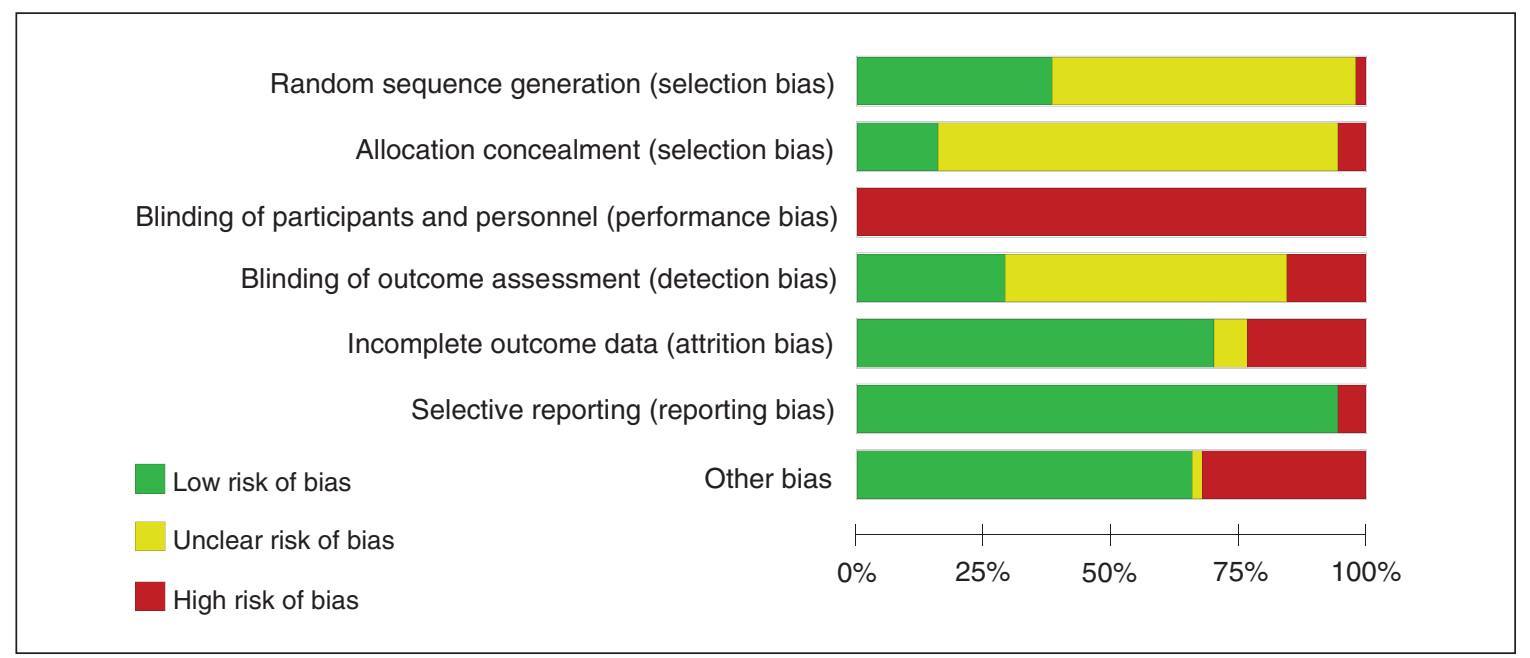

Figure 2: Aggregated risk-of-bias assessment of included studies. Summary data from each study are available in Appendix 2 (www.cmajopen.ca/content/3/1/E23/suppl/DC1). 
high). For BMI alone, we did a single sensitivity analysis based on intervention type.

The outcome of change in the prevalence of overweight and obesity in children and adolescents pre- and postintervention compared with the control group underwent meta-analysis using the difference in risk ratio $\left(\mathrm{RR}_{\text {Intervention }}-\mathrm{RR}_{\text {Control }}\right)$ and its standard error (SE), and the summary measures of effect were generated using the DerSimonian and Laird random-effects model with inverse variance. ${ }^{26}$ The estimate of absolute risk reduction and number needed to treat were calculated based on the prevalence of overweight and obesity postintervention.

Efficacious interventions were identified from studies in the meta-analysis of BMI and BMI z-score that significantly favoured the intervention group at postassessment. The choice of intervention characteristics to examine (target sex and age, estimated number or frequency of sessions, group sessions, family involvement and staff training) was informed

Table 1: Summary of study characteristics

\begin{tabular}{|c|c|}
\hline Design & Ninety randomized controlled trials \\
\hline Populations & $\begin{array}{l}\text { - Not limited to children who are normal weight } \\
\text { (overweight and obese children included in most } \\
\text { studies) } \\
\text { - Twenty interventions involved children aged } 0-5 \\
\text { years, } 53 \text { involved children aged } 6-12 \text { years, } \\
\text { and } 17 \text { involved youth aged } 13-18 \text { years } \\
\text { - Seventy-six studies included boys and girls, } 11 \\
\text { included only girls and } 3 \text { included only boys }\end{array}$ \\
\hline Interventions & $\begin{array}{l}\text { - Sixteen diet interventions, } 20 \text { exercise } \\
\text { interventions, } 32 \text { diet-plus-exercise interventions } \\
\text { and } 22 \text { lifestyle interventions } \\
\text { - Sixty-two studies had intervention arms in } \\
\text { educational settings, } 19 \text { had intervention arms in } \\
\text { noneducational settings, } 8 \text { had intervention } \\
\text { arms in education plus other settings and } 1 \\
\text { study had } 2 \text { intervention arms (one offered only } \\
\text { in an education setting and one offered in } \\
\text { education plus other settings) } \\
\text { - Twenty-one interventions used interactive } \\
\text { education approaches; } 25 \text { used behavioural } \\
\text { approaches; } 8 \text { used therapy, management or } \\
\text { counselling; and } 36 \text { used multicomponent } \\
\text { strategies } \\
\text { - Sixty-one interventions ( } 68 \%) \text { were } 12 \text { months } \\
\text { or less in duration; } 87 \text { interventions ( } 97 \% \text { ) were } \\
3 \text { years or less in duration }\end{array}$ \\
\hline $\begin{array}{l}\text { Quality } \\
\text { assessment }\end{array}$ & $\begin{array}{l}\text { - Sixty-eight studies (76\%) were published } \\
\text { between } 2009 \text { and } 2013 ; 22(24 \%) \text { were } \\
\text { published between } 1998 \text { and } 2008 \\
\text { - Most outcomes received very low quality ratings } \\
\text { (downgraded for risk of bias, inconsistency or } \\
\text { indirectness; sometimes also downgraded for } \\
\text { imprecision and occasionally for reporting bias) }\end{array}$ \\
\hline $\begin{array}{l}\text { Study } \\
\text { locations }\end{array}$ & $\begin{array}{l}\text { - Two studies in Canada; } 1 \text { in Canada and the US; } \\
39 \text { in the US; } 29 \text { in Europe; } 9 \text { in Australia; } 2 \text { in } \\
\text { Brazil; } 2 \text { in Israel; and } 1 \text { in each of China, Egypt, } \\
\text { India, Mexico, New Zealand and Thailand }\end{array}$ \\
\hline $\begin{array}{l}\text { Publication } \\
\text { dates }\end{array}$ & $\begin{array}{l}\text { - Sixty-eight studies (76\%) were published } \\
\text { between } 2009 \text { and 2013; } 22(24 \%) \text { were } \\
\text { published between } 1998 \text { and } 2008\end{array}$ \\
\hline
\end{tabular}

by a similar list in another systematic review, ${ }^{13}$ to which we added intervention duration, type and setting, based on our belief that primary care professionals might want to consider these features when making referrals or recommending programs to their patients and their families.

\section{Results}

Figure 1 presents the search and selection results. We included 123 papers representing 90 studies. This total includes 28 studies from the 2011 Cochrane review, ${ }^{28-55} 16$ studies the Cochrane group was considering for their update, ${ }^{56-71} 10$ studies from the pool of as yet unreviewed citations from the Cochrane group (some of which were also found by our search) $)^{72-81}$ and 36 unique studies identified in our search. ${ }^{82-117}$ Ratings for risk of bias in individual studies were mostly unclear or high (Figure 2; see Appendix 2 for details about individual studies, www.cmajopen.ca/content/3/1/E23/suppl /DC1). Table 1 provides a summary of the features of the included body of evidence (see Appendix 3 for details about individual studies, www.cmajopen.ca/content/3/1/E23/suppl /DC1). The weight range of children in the studies varied (i.e., they were unselected or mixed-weight populations, not populations solely of children who were normal weight).

\section{Change in body mass index and body mass index z-score}

Seventy-six studies were included in the meta-analysis assessing change in BMI and BMI z-score. ${ }^{28-47,49-62,64-66,68-74,77-90,94,95}$, 97,98,100-104,107-109,111-113,115-117 Figure 3 shows a small but significant effect in the intervention group compared with control groups (also Table 2). Tests for subgroup differences showed no differences in effect on BMI and BMI z-score across treatment type, intervention duration, participants' sex or age, or study risk-of-bias rating, but did show a difference depending on intervention setting (Table 2). Interventions in education settings showed significant improvements for program participants compared with controls, whereas programs located in noneducation settings or in combined education plus other settings showed no difference (Table 2). Subanalysis by intervention type found only diet-plus-exercise participants had a significantly lowered BMI and BMI z-score compared with controls (Table 2). Both boys and girls who took part in interventions showed significantly better results than control groups (Table 2). Improvements were observed for children participating in interventions who were aged 6-12 years and for youth, but not for children aged $0-5$ years (Table 2 ). Interventions lasting 1 year or less demonstrated significant benefits for participants compared with control groups, but longer programs did not (Table 2). Finally, more improvement was observed in the intervention group compared with the control group across all levels of study risk of bias (Table 2).

Eight trials met the inclusion criteria but could not be pooled because 1) baseline or follow-up values were missing, and no change from baseline data were provided; 2) only an effect size or $\mathrm{p}$ value was reported without group-level data, or 3) only general statements were made that no difference 
between study groups was observed at postassessment. ${ }^{63,67,76,96 \text {, }}$ 99,106,110,114 Most of these studies reported no significant difference in BMI changes or BMI z-scores between intervention and control groups. ${ }^{63,67,76,99,110,114}$ One study by Wen and colleagues ${ }^{96}$ reported a significantly lower mean BMI for children participating in the intervention compared with control participants. In a randomized intervention study, Bellows and colleagues $^{106}$ observed different effects based on age and weight status; 3 - to 5-year-olds and children who were already overweight or obese showed no increase in BMI, but 4- to 5 -year-olds and children who were normal weight showed increasing BMI.

\section{Change in body mass index}

Fifty-seven trials were included in the meta-analysis assessing

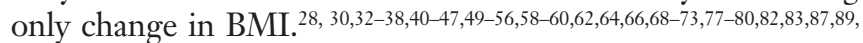
94,95,97,98,101,103,104,107,108,113,115,116 A small but significant change favouring intervention participants was observed compared with control-group participants (Table 2). After a subgroup analysis based on intervention type (diet, exercise, diet plus exercise or lifestyle), the effect was only significant for dietplus-exercise programs compared with control conditions (MD $-0.15 \mathrm{~kg} / \mathrm{m}^{2}, 95 \%$ confidence interval $[\mathrm{CI}]-0.25$ to $\left.-0.03, I^{2}=76 \%\right)$.

\section{Change in prevalence of overweight and obesity}

Thirty studies were included in the meta-analysis assessing change in prevalence of overweight and obesity (Figure 4). ${ }^{28,29}$, $33,38,42,45,46,48,57,58,61,62,69,71,72,75,78,81,85-87,91-95,102,105,115,116$ Intervention participants were more likely to show a reduction in prevalence and less risk of being overweight or obese compared with control participants: $39.8 \%$ of participants were overweight or obese at preintervention to $35.3 \%$ of participants at postintervention compared with $33.4 \%$ overweight or obese at baseline to $31.5 \%$ at postassessment (ratio of RR $0.94,95 \%$ CI 0.89 to $0.99, I^{2}=0 \%$; absolute RR $1.96 \%$, number needed to treat 51 , $95 \%$ CI 29 to 289). In a cluster-randomized trial that could not be pooled, Bürgi and colleagues ${ }^{94}$ reported no difference in the change in prevalence of overweight in children who had completed a lifestyle intervention focusing on physical activity, nutrition education, screen time and sleep.

\section{Harms}

Only 3 studies were found that addressed the identified harms. A school-based diet intervention study by Foster and colleagues $^{42}$ reported on negative impacts on body image and suggested that there was no difference between groups, but no data was provided. A study by de Heer and colleagues ${ }^{56}$ reported a diet-plus-exercise intervention was delivered without any major incidents. The third study by Yin and colleagues ${ }^{117}$ examined the effects of a physical activity program on more than 500 elementary school children reported 43 events and adverse event incident rates of 0.03 in year 1 , 0.02 in year 2 and 0.01 in year 3 . No examples of adverse events were provided in the study, but the authors reported that $67 \%$ were mild in nature, $21 \%$ were moderate and $12 \%$ were severe. ${ }^{117}$

\section{Features of efficacious interventions}

Sixteen studies showed a significant benefit of intervention compared with the control groups in terms of a reduced BMI and BMI z-score at postassessment (see Figure 3). Interventions in these studies were designated as efficacious; Table 3 presents their individual features. Overall, 14 programs were situated in educational settings, 15 involved group sessions, 4 incorporated family involvement and 6 specified that staff training was provided. Intervention duration ranged from 12 weeks to 3 years. Ten programs lasted 1 year or less and 8 were in place for 6 months or less. Most interventions $(n=13)$ were offered to mixed-sex groups and more than half $(n=9)$ involved children who were elementary school age. Intervention type varied (diet $[n=4]$, exercise $[n=5]$, diet plus exercise $[n=5]$ and lifestyle $[n=2]$ ) as did location (Europe $[n=7]$, United States $[n=4]$, Australia $[n=2]$, China $[n=1]$, Egypt $[n=1]$ and Israel $[n=1])$.

\section{Interpretation}

\section{Main findings}

We found a substantial number of studies that involved mixed-weight populations and no studies exclusively involving normal-weight children; therefore, we cannot determine the effectiveness of the interventions for prevention of weight gain for that specific group. Compared with the control groups, prevention interventions in mixed-weight populations of children and adolescents showed a small effect in terms of a lowered BMI and BMI z-score and a reduced prevalence of overweight and obesity. For overweight or obese children and youth, these changes are not clinically meaningful, although for preventing unhealthy weight gain, they could become clinically meaningful over time. Program benefits must be considered against harms. Only 3 of the 90 included studies reported on adverse consequences of participation; therefore, we are unable to draw conclusions regarding harmful effects of prevention interventions. Many efficacious interventions lasted less than 1 year, involved children who were elementary school age and were implemented in educational settings, but there was too much variation across programs to isolate any determining features of effectiveness.

Our updated review added 62 studies to the evidence included in the most recent Cochrane Review. ${ }^{17}$ The overall findings of this review are similar to other recent reviews that included school-based interventions for the prevention of obesity in children and adolescents. ${ }^{14,17,18}$ Some differences were observed across subgroup analyses: for example, we found a small but significant effect for change in BMI and BMI z-score for youth aged 13-18 years that was not observed in the Cochrane Review. ${ }^{17} \mathrm{We}$ also used a more rigorous approach for subgrouping intervention type by adding a lifestyle category to better reflect current evidence. Furthermore, going beyond conventional measures of adiposity (e.g., $\mathrm{BMI}$ and BMI z-score) used by previous reviews, ${ }^{13,17}$ we also looked at prevalence of overweight and obesity to help inform the direction of evidence in a more intuitive way. Consistent with other reviews, we found no studies involving primary 


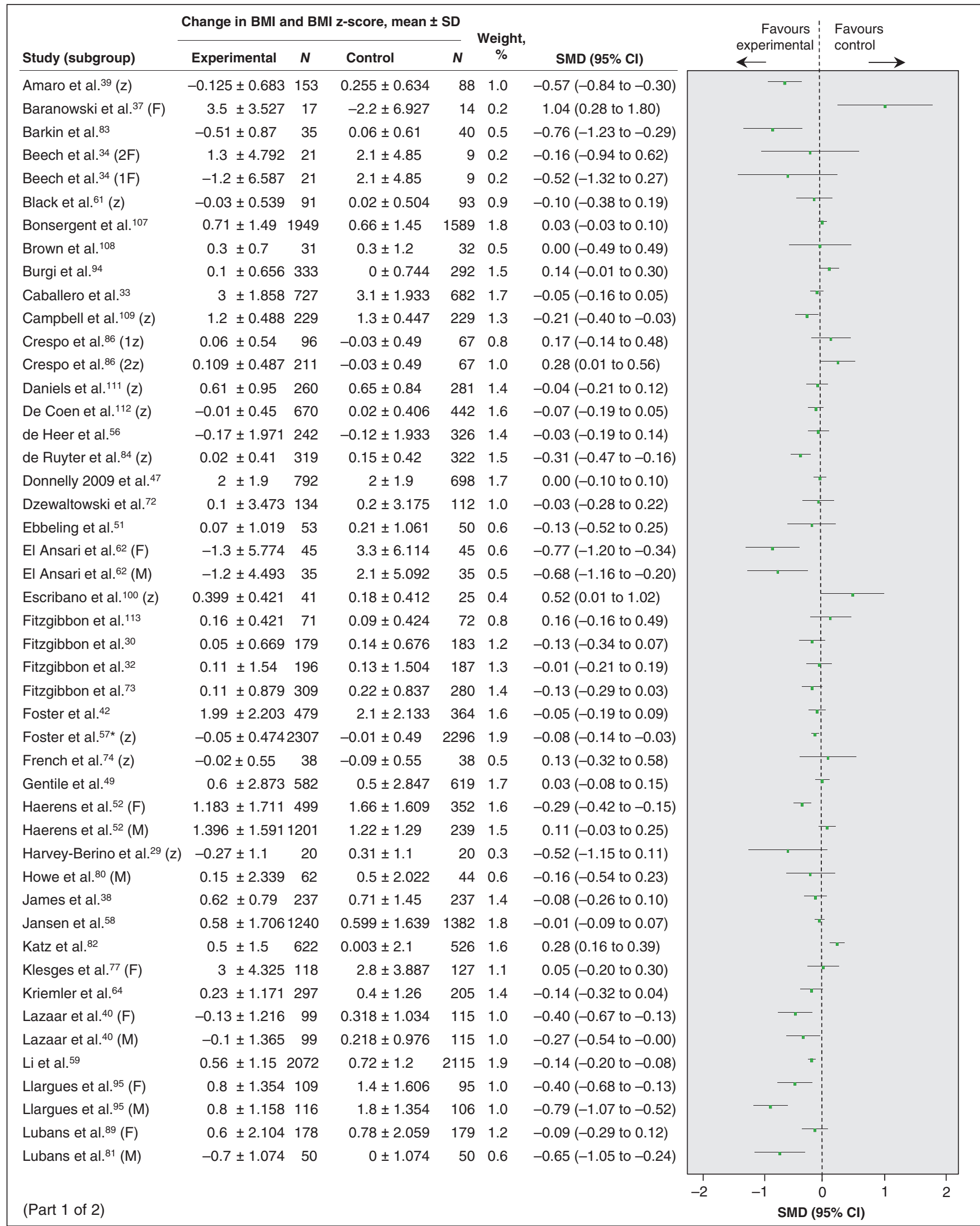

Figure 3A: (See Figure 3B for part 2). Effect of prevention interventions on change in body mass index (BMI) and BMI z-score. Values less than 0 indicate a change in $\mathrm{BMI}$ in favour of the intervention. $1=$ intervention arm 1;2 = intervention $\operatorname{arm} 2 ; \mathrm{Cl}=$ confidence interval; $\mathrm{F}=$ female; $\mathrm{M}=$ male; SD = standard deviation; SMD = standardized mean difference; $z$ = BMI z-score. 


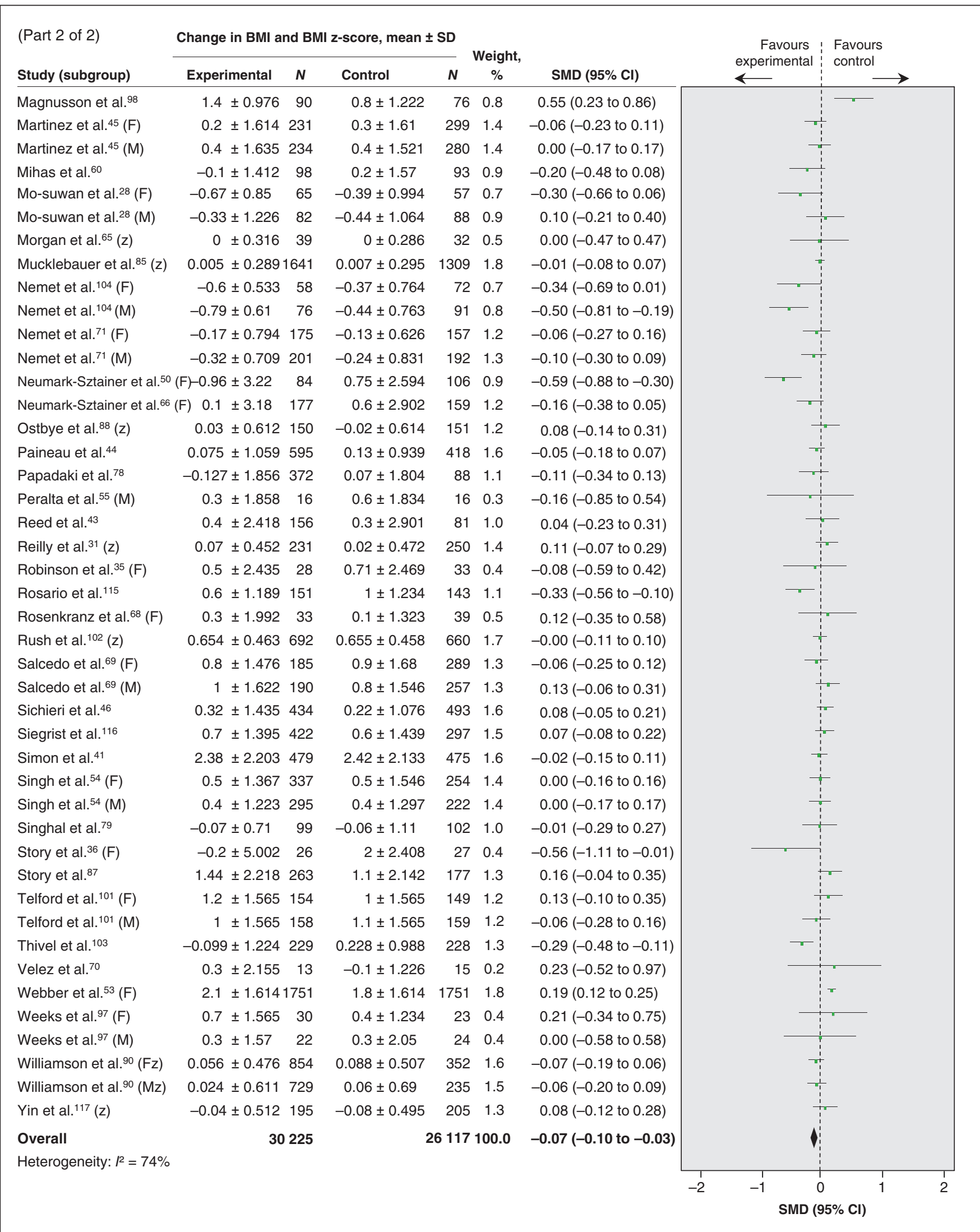

Figure 3B: Effect of prevention interventions on change in body mass index (BMI) and BMI Z-score. Values less than 0 indicate a change in $\mathrm{BMI}$ in favour of the intervention. $1=$ intervention arm $1 ; 2=$ intervention arm $2 ; \mathrm{Cl}=$ confidence interval; $\mathrm{F}=$ female; $\mathrm{M}=$ male; $\mathrm{SD}=\mathrm{standard}$ deviation; SMD = standardized mean difference; $\mathrm{z}=\mathrm{BMI}$ z-score. 


\section{OPEN}

Research

prevention of weight gain in children who were normal weight. It is not surprising that primary prevention programs have not been evaluated. It would be hard to separate out normal-weight children in a school population, to motivate them to attend an out-of-classroom intervention, or to motivate most parents of these children to take them to a community intervention for weight maintenance. It is unlikely that a randomized trial will be done.

\section{Limitations}

First, the included studies involved mixed-weight populations; thus, we cannot directly answer the question of weightgain prevention specifically in normal-weight children and adolescents. Second, risk of bias was unclear in most studies, primarily because of the lack of information about or lack of procedures to ensure random sequence generation, allocation concealment and blinding of participants, personnel and outcome assessment, and other sources of bias (i.e., study underpowered or analysis did not account for clustering). Potential reporting bias was also identified across a number of outcome and comparison-based study groupings. Third, statistical heterogeneity was high for the outcome of BMI and BMI Z-score, which could primarily be attributed to small versus large treatment effects observed across studies (Figure 3). Other possible factors for heterogeneity (e.g., intervention type, setting and duration, participants' sex and age, and

Table 2: Effect of intervention on change in BMI and BMI z-score by group or subgroup

\begin{tabular}{|c|c|c|c|c|c|c|c|c|}
\hline Group or subgroup & $\begin{array}{l}\text { Meta-analysis, } \\
\quad(95 \% \mathrm{Cl})\end{array}$ & \multicolumn{2}{|c|}{$\begin{array}{c}\text { Statistical heterogeneity } \\
\text { (within-group), } \\
p \text { value ( } I^{2} \text { value, \%) }\end{array}$} & \multicolumn{2}{|c|}{$\begin{array}{l}\text { Test for between- } \\
\text { group differences, } \\
p \text { value }\left(I^{2} \text { value, } \%\right)\end{array}$} & $\begin{array}{c}\text { No. of } \\
\text { participants }\end{array}$ & $\begin{array}{l}\text { No. of } \\
\text { studies }\end{array}$ & $\begin{array}{l}\text { Quality of } \\
\text { evidence } \\
\text { rating }\end{array}$ \\
\hline Overall & $-0.07(-0.10$ to -0.03$)$ & $<0.001$ & $(74)$ & \multicolumn{2}{|c|}{ NA } & 56342 & 76 & Very low \\
\hline \multicolumn{9}{|l|}{ Intervention } \\
\hline Diet + exercise & $-0.10(-0.17$ to -0.03$)$ & $<0.001$ & $(70)$ & \multirow{2}{*}{0.19} & \multirow{2}{*}{ (37) } & 14923 & 26 & Very low \\
\hline Lifestyle & $-0.00(-0.06$ to 0.06$)$ & 0.004 & (53) & & & 13949 & 17 & Very low \\
\hline \multicolumn{9}{|l|}{ Setting } \\
\hline Noneducation & $-0.04(-0.15$ to 0.08$)$ & 0.01 & $(46)$ & 0.04 & $(68)$ & 3070 & 18 & Very low \\
\hline$\geq 12 \mathrm{mo}$ & $-0.08(-0.13$ to -0.03$)$ & $<0.001$ & (67) & \multirow{2}{*}{\multicolumn{2}{|c|}{0.32}} & 28220 & 54 & Very low \\
\hline$>12 \mathrm{mo}$ & $-0.04(-0.11$ to 0.02$)$ & $<0.001$ & (82) & & & 28122 & 22 & Very low \\
\hline \multicolumn{9}{|l|}{ Sex } \\
\hline Male & $-0.16(-0.29$ to -0.03$)$ & $<0.001$ & $(77)$ & \multirow{2}{*}{\multicolumn{2}{|c|}{$0.76 \quad(0)$}} & 5719 & 16 & Very low \\
\hline Female & $-0.14(-0.24$ to -0.03$)$ & $<0.001$ & $(80)$ & & & 10007 & 23 & Very low \\
\hline \multicolumn{9}{|l|}{ Age, yr } \\
\hline $0-5$ & $-0.06(-0.15$ to 0.02$)$ & 0.001 & (62) & \multirow{2}{*}{\multicolumn{2}{|c|}{$0.54 \quad(0)$}} & 6930 & 17 & Very low \\
\hline $6-12$ & $-0.06(-0.10$ to -0.01$)$ & $<0.001$ & (73) & & & 36916 & 42 & Very low \\
\hline Overall & $-0.09(-0.16$ to -0.03$)$ & $<0.001$ & $(76)$ & $\mathrm{N}$ & & 40214 & 57 & Very low \\
\hline
\end{tabular}


study risk of bias) were explored (see Table 2). Fourth, because we only looked at features of interventions that showed a significant benefit over the control condition, we cannot comment whether these characteristics differ in any way from interventions that failed to show a difference.
Finally, a language filter was applied in our search because of limited resources available to appropriately handle (e.g., screening, translation and interpretation) publications in other languages; therefore, only publications in English or French were captured by our search.

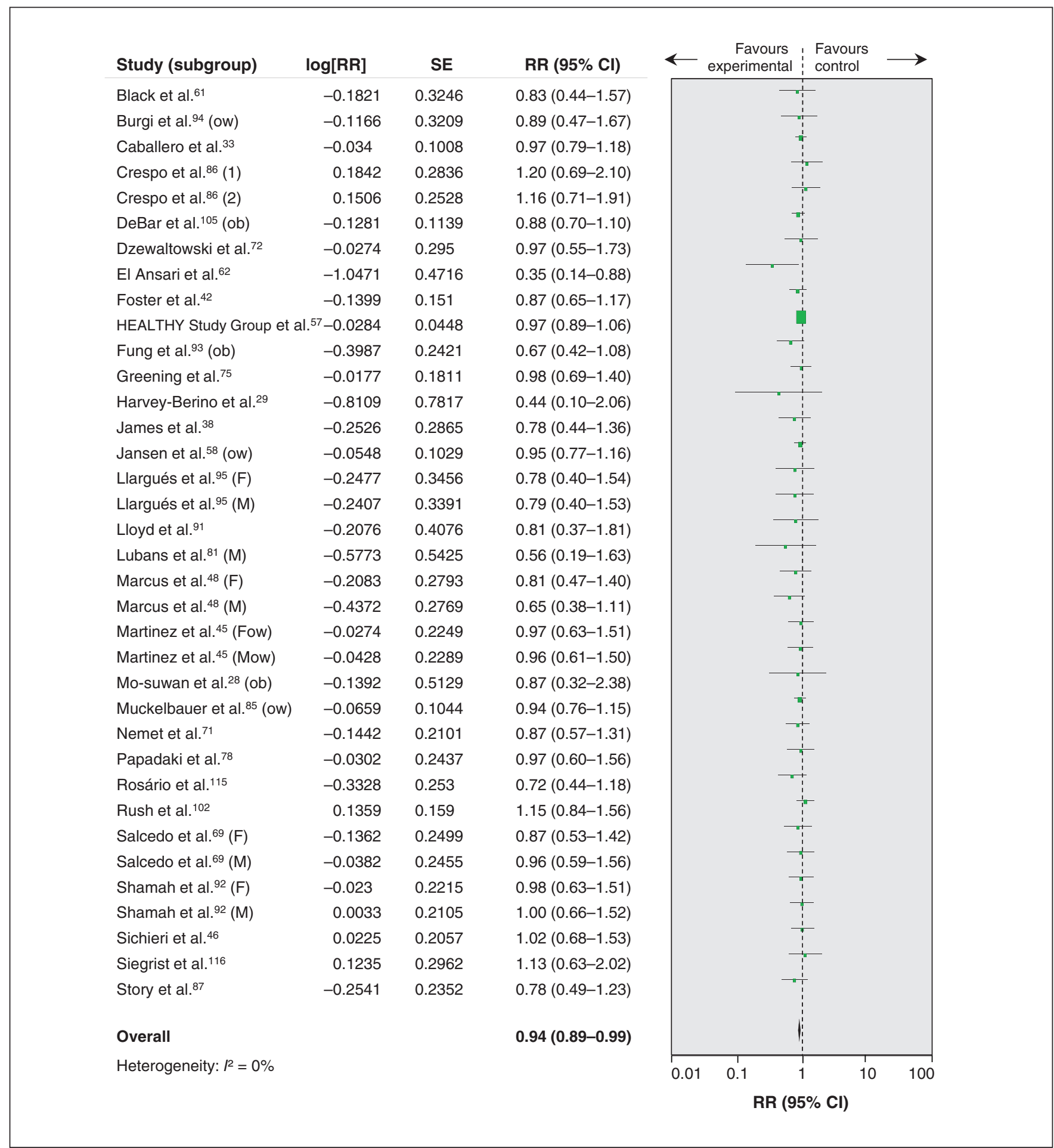

Figure 4: Effect of prevention interventions on change in prevalence of overweight or obesity. Values less than 1 indicate a change in prevalence of overweight or obesity in favour of the intervention. $1=$ intervention arm 1;2 = intervention arm 2; F = female; $\mathrm{M}=$ male; ob =obese, ow = overweight (overweight and obese are not combined in either extension); $\mathrm{RR}=$ risk ratio. 
Table 3: Characteristics of efficacious interventions

\begin{tabular}{|c|c|c|c|c|c|c|c|c|c|}
\hline Study & Sex & $\begin{array}{l}\text { Target } \\
\text { age, yr }\end{array}$ & $\begin{array}{l}\text { Intervention } \\
\text { duration }\end{array}$ & $\begin{array}{l}\text { Estimated no. or } \\
\text { frequency of } \\
\text { sessions }\end{array}$ & $\begin{array}{c}\text { Type of } \\
\text { intervention }\end{array}$ & $\begin{array}{l}\text { Intervention } \\
\text { setting }\end{array}$ & $\begin{array}{l}\text { Group } \\
\text { sessions }\end{array}$ & $\begin{array}{c}\text { Family } \\
\text { involvement }\end{array}$ & $\begin{array}{l}\text { Staff } \\
\text { training }\end{array}$ \\
\hline Amaro et al., $2006^{39}$ & $M+F$ & $6-12$ & 24 wk & $1 \times / w k$ & Diet & E & Yes & - & - \\
\hline Barkin et al., $2012^{83}$ & $M+F$ & $0-5$ & 12 wk & $1 \times /$ wk & Diet + exercise & $\mathrm{N}$ & Yes & Yes & - \\
\hline Campbell et al., $2013^{109}$ & $M+F$ & $0-5$ & $15 \mathrm{mo}$ & 6 2-h sessions & Diet & $\mathrm{N}$ & Yes & Yes & - \\
\hline de Ruyter et al., $2012^{84}$ & $M+F$ & $6-12$ & $1.5 \mathrm{yr}$ & $\begin{array}{l}\text { Daily beverage } \\
\text { consumption }\end{array}$ & Diet & $E$ & - & - & - \\
\hline El Ansari et al., $2010^{62}$ & $M+F$ & $13-18$ & $3 \mathrm{mo}$ & $2 \times / w k$ & Exercise & E & Yes & - & - \\
\hline Haerens et al., $2006^{52}$ & $M+F$ & $13-18$ & $2 \mathrm{yr}$ & Unclear & Diet + exercise & $E$ & Yes & - & Yes \\
\hline $\begin{array}{l}\text { Healthy Study Group } \\
\text { et al., } 2010^{57}\end{array}$ & $M+F$ & $6-12$ & $3 y r$ & Unclear & Diet + exercise & $E$ & Yes & Yes & Yes \\
\hline Lazaar et al., $2007^{40}$ & $M+F$ & $6-12$ & $6 \mathrm{mo}$ & $2 \times /$ wk & Exercise & $E$ & Yes & - & - \\
\hline Li et al., $2010^{59}$ & $M+F$ & $6-12$ & $1 \mathrm{yr}$ & $2 \times / d$ & Exercise & E & Yes & - & - \\
\hline Llargues et al., $2012^{95}$ & $M+F$ & $6-12$ & $2 \mathrm{yr}$ & Unclear & Diet + exercise & E & Yes & - & Yes \\
\hline Lubans et al., $2011^{81}$ & M & $13-18$ & $6 \mathrm{mo}$ & Unclear & Exercise & E & Yes & - & - \\
\hline Nemet et al., $2011^{104}$ & $M+F$ & $0-5$ & $10 \mathrm{mo}$ & Daily & Diet + exercise & E & Yes & - & Yes \\
\hline $\begin{array}{l}\text { Neumark-Sztainer et al., } \\
2003^{50}\end{array}$ & $\mathrm{~F}$ & $13-18$ & $16 \mathrm{wk}$ & $>4 \times / w k$ & Lifestyle & $E$ & Yes & - & Yes \\
\hline Rosario et al., $2013^{115}$ & $M+F$ & $6-12$ & $2 \mathrm{yr}$ & 12 sessions & Diet & E & Yes & - & Yes \\
\hline Story et al., $2003^{36}$ & $\mathrm{~F}$ & $6-12$ & $3 \mathrm{mo}$ & $2 \times / w k$ & Lifestyle & $\mathrm{E}+$ other & Yes & Yes & - \\
\hline Thivel et al., $2011^{103}$ & $M+F$ & $6-12$ & $6 \mathrm{mo}$ & $2 \mathrm{~h} / \mathrm{wk}$ & Exercise & E & Yes & - & - \\
\hline
\end{tabular}

\section{Conclusion}

Small improvements in weight outcomes with questionable clinical importance were found. The small magnitude of effect observed across studies suggests the need for trials with larger sample sizes that are powered to detect small differences across subgroups. Moreover, the paucity of studies involving very young children warrants further research in this context. Finally, the diversity of intervention strategies and unexplained heterogeneity limits the generalizability of the small effect found in our review for a mixed-weight population; future research involving normal-weight children is required.

\section{References}

1. Eckersley RM. Losing the battle of the bulge: causes and consequences of increasing obesity. Med 7 Aust 2001;174:590-2.

2. Mokdad AH, Ford ES, Bowman BA, et al. Prevalence of obesity, diabetes, and obesity-related health risk factors, 2001. 7AMA 2003;289:76-9.

3. Flegal KM, Graubard BI, Williamson DF, et al. Excess deaths associated with underweight, overweight, and obesity. FAMA 2005;293:1861-7.

4. Allison DB, Fontaine KR, Manson JE, et al. Annual deaths attributable to obesity in the United States. FAMA 1999;282:1530-8.

5. Wilson PW, D'Agostino RB, Sullivan L, et al. Overweight and obesity as determinants of cardiovascular risk: the Framingham experience. Arcb Intern Med 2002;162:1867-72.

6. Dietitians of Canada, Canadian Paediatric Society, The College of Family Physicians of Canada, Community Health Nurses of Canada. Promoting optimal monitoring of child growth in Canada: using the new World Health Organization growth charts. 2010. Available: www.dietitians.ca/growthcharts (accessed 2014 Oct. 24).

7. Ho M, Garnett SP, Baur LA, et al. Impact of dietary and exercise interventions on weight change and metabolic outcomes in obese children and adolescents: a systematic review and meta-analysis of randomized trials. FAMA Pediatr 2013;167:759-68.
8. Hoelscher DM, Kirk S, Ritchie L, et al. Position of the Academy of Nutrition and Dietetics: interventions for the prevention and treatment of pediatric overweight and obesity. 7 Acad Nutr Diet 2013;113:1375-94.

9. Kothandan SK. School based interventions versus family based interventions in the treatment of childhood obesity - a systematic review. Arch Public Health 2014;72:3.

10. Kelley GA, Kelley KS. Effects of exercise in the treatment of overweight and obese children and adolescents: a systematic review of meta-analyses. 7 Obes 2013;2013:783103.

11. Ewald H, Kirby J, Rees K, et al. Parent-only interventions in the treatment of childhood obesity: a systematic review of randomized controlled trials. $\mathcal{F}$ Public Health (Oxf) 2014;36:476-89.

12. McDonagh MS, Selph S, Ozpinar A, et al. Systematic review of the benefits and risks of metformin in treating obesity in children aged 18 years and younger. FAMA Pediatr 2014;168:178-84.

13. Whitlock EP, O'Connor EA, Williams SB, et al. Effectiveness of primary care interventions for weight management in children and adolescents: an updated, targeted systematic review for the USPSTF. No. 76 of Evidence Syntheses series. Rockville (MD): Agency for Healthcare Research and Quality; 2010. Report No: 10-05144-EF-1

14. Wang Y, Wu Y, Wilson RF, et al. Childhood obesity prevention programs: comparative effectiveness review and meta-analysis. No. 115 of Comparative Effectiveness Review. Rockville (MD): Agency for Healthcare Research and Quality; 2013. Report No: 13-EHC081-E.

15. Bleich SN, Segal J, Wu Y, et al. Systematic review of community-based childhood obesity prevention studies. Pediatrics 2013;132:e201-10.

16. Showell NN, Fawole O, Segal J, et al. A systematic review of home-based childhood obesity prevention studies. Pediatrics 2013;132:e193-200.

17. Waters E, de Silva-Sanigorski A, Hall BJ, et al. Interventions for preventing obesity in children. Database Syst Rev 2011;(12):CD001871.

18. Sobol-Goldberg S, Rabinowitz J, Gross R. School-based obesity prevention programs: a meta-analysis of randomized controlled trials. Obesity (Silver Spring) 2013;21:2422-8.

19. Silveira JACD, Taddei JADA, Guerra PH, et al. The effect of participation in school-based nutrition education interventions on body mass index: a metaanalysis of randomized controlled community trials. Prev Med 2013;56:237-43.

20. Sbruzzi G, Eibel B, Barbiero SM, et al. Educational interventions in childhood obesity: a systematic review with meta-analysis of randomized clinical trials. Prev Med 2013;56:254-64. 
21. Wahi G, Parkin PC, Beyene J, et al. Effectiveness of interventions aimed at reducing screen time in children: a systematic review and meta-analysis of randomized controlled trials. Arch Pediatr Adolesc Med 2011;165:979-86.

22. Martin J, Chater A, Lorencatto F. Effective behaviour change techniques in the prevention and management of childhood obesity. Int 7 Obes (Lond) 2013;37:1287-94

23. Shea BJ, Grimshaw JM, Wells GA, et al. Development of AMSTAR: a measurement tool to assess the methodological quality of systematic reviews. $B M C$ Med Res Methodol 2007;7:10.

24. Cochrane handbook for systematic reviews of interventions. Version 5.1.0. New York: John Wiley \& Sons, Ltd. Publications; 2011.

25. Grading of Recommendations, Assessment, Development and Evaluation (GRADE) Working Group. GRADE; 2000. Introduction. Available: www gradeworkinggroup.org/.

26. DerSimonian R, Laird N. Meta-analysis in clinical trials. Control Clin Trials 1986;7:177-88

27. Cohen J. Statistical power analysis for the behavioral sciences. $2 \mathrm{nd}$ ed. Hillsdale (NJ): Erlbaum; 1988.

28. Mo-suwan L, Pongprapai S, Junjana C, et al. Effects of a controlled trial of a school-based exercise program on the obesity indexes of preschool children. Am 7 Clin Nutr 1998;68:1006-11.

29. Harvey-Berino J, Rourke J. Obesity prevention in preschool Native-American children: a pilot study using home visiting. Obes Res 2003;11:606-11.

30. Fitzgibbon ML, Stolley MR, Schiffer L, et al. Two-year follow-up results for Hip-Hop to Health Jr.: a randomized controlled trial for overweight prevention in preschool minority children. 7 Pediatr 2005;146:618-25.

31. Reilly JJ, Kelly L, Montgomery C, et al. Physical activity to prevent obesity in young children: cluster randomised controlled trial. BM7 2006;333:1041.

32. Fitzgibbon ML, Stolley MR, Schiffer L, et al. Hip-Hop to Health Jr. for Latino preschool children. Obesity (Silver Spring) 2006;14:1616-25.

33. Caballero B, Clay T, Davis SM, et al. Pathways: a school-based, randomized controlled trial for the prevention of obesity in American Indian schoolchildren. Am 7 Clin Nutr 2003;78:1030-8.

34. Beech BM, Klesges RC, Kumanyika SK, et al. Child- and parent-targeted interventions: the Memphis GEMS pilot study. Ethn Dis 2003;13(Suppl 1):S40-53

35. Robinson TN, Killen JD, Kraemer HC, et al. Dance and reducing television viewing to prevent weight gain in African-American girls: the Stanford GEMS pilot study. Ethn Dis 2003;13(Suppl 1):S65-77.

36. Story M, Sherwood NE, Himes JH, et al. An after-school obesity prevention program for African-American girls: the Minnesota GEMS pilot study. Ethn Dis 2003;13(Suppl 1):S54-64.

37. Baranowski T, Baranowski JC, Cullen KW, et al. The Fun, Food, and Fitness Project (FFFP): the Baylor GEMS pilot study. Ethn Dis 2003;13(Suppl 1):S30-9.

38. James J, Thomas P, Cavan D, et al. Preventing childhood obesity by reducing consumption of carbonated drinks: cluster randomised controlled trial [published erratum in BM7 2004;328:1236]. BM7 2004;328:1237.

39. Amaro S, Viggiano A, Di Costanzo A, et al. Kalèdo, a new educational boardgame, gives nutritional rudiments and encourages healthy eating in children: a pilot cluster randomized trial. Eur 7 Pediatr 2006;165:630-5.

40. Lazaar N, Aucouturier J, Ratel S, et al. Effect of physical activity intervention on body composition in young children: influence of body mass index status and gender. Acta Paediatr 2007;96:1315-20.

41. Simon C, Schweitzer B, Oujaa M, et al. Successful overweight prevention in adolescents by increasing physical activity: a 4-year randomized controlled intervention [published erratum in Int 7 Obes (Lond) 2008;32:1606]. Int 7 Obes (Lond) 2008:32:1489-98.

42. Foster GD, Sherman S, Borradaile KE, et al. A policy-based school intervention to prevent overweight and obesity. Pediatrics 2008;121:e794-802.

43. Reed KE, Warburton DE, Macdonald HM, et al. Action Schools! BC: a school-based physical activity intervention designed to decrease cardiovascular disease risk factors in children. Prev Med 2008;46:525-31.

44. Paineau DL, Beaufils F, Boulier A, et al. Family dietary coaching to improve nutritional intakes and body weight control: a randomized controlled trial. Arch Pediatr Adolesc Med 2008;162:34-43

45. Martínez Vizcaíno V, Salcedo AF, Franquelo Gutiérrez R, et al. Assessment of an after-school physical activity program to prevent obesity among 9- to 10-year-old children: a cluster randomized trial. Int 7 Obes (Lond) 2008; $32: 12-22$.

46. Sichieri R, Paula TA, de Souza RA, et al. School randomised trial on prevention of excessive weight gain by discouraging students from drinking sodas. Public Health Nutr 2009;12:197-202.

47. Donnelly JE, Greene JL, Gibson CA, et al. Physical Activity Across the Curriculum (PAAC): a randomized controlled trial to promote physical activity and diminish overweight and obesity in elementary school children. Prev Med 2009; 49:336-41.

48. Marcus C, Nyberg G, Nordenfelt A, et al. A 4-year, cluster-randomized, controlled childhood obesity prevention study: STOPP. Int 7 Obes (Lond) 2009;33:408-17.

49. Gentile DA, Welk G, Eisenmann JC, et al. Evaluation of a multiple ecological level child obesity prevention program: Switch what you Do, View, and Chew. BMC Med 2009;7:49.
50. Neumark-Sztainer D, Story M, Hannan PJ, et al. New Moves: a school-based obesity prevention program for adolescent girls. Prev Med 2003;37:41-51.

51. Ebbeling CB, Feldman HA, Osganian SK, et al. Effects of decreasing sugarsweetened beverage consumption on body weight in adolescents: a randomized, controlled pilot study. Pediatrics 2006;117:673-80.

52. Haerens L, Deforche B, Maes L, et al. Evaluation of a 2-year physical activity and healthy eating intervention in middle school children. Health Educ Res 2006;21:911-21.

53. Webber LS, Catellier DJ, Lytle LA, et al. Promoting physical activity in middle school girls: Trial of Activity for Adolescent Girls. Am 7 Prev Med 2008; 34:173-84.

54. Singh AS, Chin APM, Brug J, et al. Dutch obesity intervention in teenagers: effectiveness of a school-based program on body composition and behavior. Arch Pediatr Adolesc Med 2009;163:309-17.

55. Peralta LR, Jones RA, Okely AD. Promoting healthy lifestyles among adolescent boys: the Fitness Improvement and Lifestyle Awareness Program RCT. Prev Med 2009; 48:537-42.

56. de Heer HD, Koehly L, Pederson R, et al. Effectiveness and spillover of an afterschool health promotion program for Hispanic elementary school children. Am $\mathcal{F}$ Public Health 2011;101:1907-13

57. HEALTHY study group, Foster GD, Linder B, et al. A school-based intervention for diabetes risk reduction. N Engl f Med 2010;363:443-53.

58. Jansen W, Borsboom G, Meima A, et al. Effectiveness of a primary schoolbased intervention to reduce overweight. Int 7 Pediatr Obes 2011;6:e70-7.

59. Li YP, Hu XQ, Schouten EG, et al. Report on childhood obesity in China (8): effects and sustainability of physical activity intervention on body composition of Chinese youth. Biomed Environ Sci 2010;23:180-7.

60. Mihas C, Mariolis A, Manios Y, et al. Evaluation of a nutrition intervention in adolescents of an urban area in Greece: short- and long-term effects of the VYRONAS study. Public Health Nutr 2010;13:712-9.

61. Black MM, Hager ER, Le K, et al. Challenge! Health promotion/obesity prevention mentorship model among urban, black adolescents. Pediatrics 2010; $126: 280-8$

62. El Ansari W, El Ashker S, Moseley L. Associations between physical activity and health parameters in adolescent pupils in Egypt. Int 7 Environ Res Public Health 2010;7:1649-69.

63. Hakanen M, Lagström H, Pahkala K, et al. Dietary and lifestyle counselling reduces the clustering of overweight-related cardiometabolic risk factors in adolescents. Acta Paediatr 2010;99:888-95.

64. Kriemler S, Zahner L, Schindler C, et al. Effect of school based physical activity programme (KISS) on fitness and adiposity in primary schoolchildren: cluster randomised controlled trial. BM7 2010;340:c785.

65. Morgan PJ, Lubans DR, Callister R, et al. The 'Healthy Dads, Healthy Kids' randomized controlled trial: efficacy of a healthy lifestyle program for overweight fathers and their children. Int 7 Obes (Lond) 2011;35:436-47.

66. Neumark-Sztainer DR, Friend SE, Flattum CF, et al. New Moves — preventing weight-related problems in adolescent girls: a group-randomized study. $\mathrm{Am}$ 7 Prev Med 2010;39:421-32.

67. Robinson TN, Matheson DM, Kraemer HC, et al. A randomized controlled trial of culturally tailored dance and reducing screen time to prevent weight gain in low-income African American girls: Stanford GEMS. Arch Pediatr Adoles Med 2010;164:995-1004.

68. Rosenkranz RR, Behrens TK, Dzewaltowski DA. A group-randomized controlled trial for health promotion in Girl Scouts: healthier troops in a SNAP (Scouting Nutrition \& Activity Program). BMC Public Health 2010;10:81.

69. Salcedo Aguilar F, Martínez-Vizcaíno V, Sánchez López M, et al. Impact of an after-school physical activity program on obesity in children. 7 Pediatr 2010; 157:36-42.e3.

70. Velez A, Golem DL, Arent SM. The impact of a 12-week resistance training program on strength, body composition, and self-concept of Hispanic adolescents. 7 Strength Cond Res 2010;24:1065-73.

71. Nemet D, Geva D, Eliakim A. Health promotion intervention in low socioeconomic kindergarten children. 7 Pediatr 2011;158:796-801.e1.

72. Dzewaltowski DA, Rosenkranz RR, Geller KS, et al. HOP'N after-school project: an obesity prevention randomized controlled trial. Int 7 Bebav Nutr Phys Act 2010;7:90.

73. Fitzgibbon ML, Stolley MR, Schiffer LA, et al. Hip-Hop to Health Jr. Obesity Prevention Effectiveness Trial: postintervention results. Obesity (Silver Spring) 2011;19:994-1003

74. French SA, Gerlach AF, Mitchell NR, et al. Household obesity prevention Take Action - a group-randomized trial. Obesity (Silver Spring) 2011;19:2082-8

75. Greening L, Harrell KT, Low AK, et al. Efficacy of a school-based childhood obesity intervention program in a rural southern community: TEAM Mississippi Project. Obesity (Silver Spring) 2011;19:1213-9.

76. Hoffman JA, Thompson DR, Franko DL, et al. Decaying behavioral effects in a randomized, multi-year fruit and vegetable intake intervention. Prev Med 2011;52:370-5.

77. Klesges RC, Obarzanek E, Kumanyika S, et al. The Memphis Girls' health Enrichment Multi-site Studies (GEMS): an evaluation of the efficacy of a 2-year obesity prevention program in African American girls. Arch Pediatr Adolesc Med 2010;164:1007-14 
78. Papadaki A, Linardakis M, Larsen TM, et al. The effect of protein and glycemic index on children's body composition: the DiOGenes randomized study. Pediatrics 2010;126:e1143-52.

79. Singhal N, Misra A, Shah P, et al. Effects of controlled school-based multicomponent model of nutrition and lifestyle interventions on behavior modification, anthropometry and metabolic risk profile of urban Asian Indian adolescents in North India. Eur 7 Clin Nutr 2010;64:364-73.

80. Howe CA, Harris RA, Gutin B. A 10-month physical activity intervention improves body composition in young black boys. 7 Obes 2011;2011:358581.

81. Lubans DR, Morgan PJ, Aguiar EJ, et al. Randomized controlled trial of the Physical Activity Leaders (PALs) program for adolescent boys from disadvantaged secondary schools. Prev Med 2011;52:239-46.

82. Katz DL, Katz CS, Treu JA, et al. Teaching healthful food choices to elementary school students and their parents: the Nutrition Detectives ${ }^{\mathrm{TM}}$ program. 7 Sch Health 2011;81:21-8.

83. Barkin SL, Gesell S, Po'e E, et al. Culturally tailored, family-centered, behavioral obesity intervention for Latino-American preschool-aged children. Pediatrics 2012;130:445-56.

84. de Ruyter JC, Olthof MR, Seidell JC, et al. A trial of sugar-free or sugar-sweetened beverages and body weight in children. N Engl 7 Med 2012;367:1397-406.

85. Muckelbauer R, Libuda L, Clausen K, et al. Promotion and provision of drinking water in schools for overweight prevention: randomized, controlled cluster trial. Nutr Today 2012;47:S27-34.

86. Crespo NC, Elder JP, Ayala GX, et al. Results of a multi-level intervention to prevent and control childhood obesity among Latino children: the Aventuras Para Niños Study. Ann Behav Med 2012;43:84-100.

87. Story M, Hannan PJ, Fulkerson JA, et al. Bright Start: description and main outcomes from a group-randomized obesity prevention trial in American Indian children. Obesity (Silver Spring) 2012;20:2241-9.

88. Østbye T, Krause KM, Stroo M, et al. Parent-focused change to prevent obesity in preschoolers: results from the KAN-DO study. Prev Med 2012:55:188-95.

89. Lubans DR, Morgan PJ, Okely AD, et al. Preventing obesity among adolescent girls: one-year outcomes of the Nutrition and Enjoyable Activity for Teen Girls (NEAT Girls) cluster randomized controlled trial. Arch Pediatr Adolesc Med 2012;166:821-7.

90. Williamson DA, Champagne CM, Harsha DW, et al. Effect of an environmental school-based obesity prevention program on changes in body fat and body weight: a randomized trial. Obesity (Silver Spring) 2012;20:1653-61.

91. Lloyd JJ, Wyatt KM, Creanor S. Behavioural and weight status outcomes from an exploratory trial of the Healthy Lifestyles Programme (HeLP): a novel school-based obesity prevention programme. BM7 Open 2012;2:e000390.

92. Shamah Levy T, Morales Ruán C, Amaya Castellanos C, et al. Effectiveness of a diet and physical activity promotion strategy on the prevention of obesity in Mexican school children. BMC Public Health 2012;12:152.

93. Fung C, Kuhle S, Lu C, et al. From "best practice" to "next practice": the effectiveness of school-based health promotion in improving healthy eating and physical activity and preventing childhood obesity. Int 7 Behav Nutr Phys Act 2012;9:27.

94. Bürgi F, Niederer I, Schindler C, et al. Effect of a lifestyle intervention on adiposity and fitness in socially disadvantaged subgroups of preschoolers: a cluster-randomized trial (Ballabeina). Prev Med 2012;54:335-40.

95. Llargués E, Recasens A, Franco R, et al. Medium-term evaluation of an educational intervention on dietary and physical exercise habits in schoolchildren: the Avall 2 study. Endocrinol Nutr 2012;59:288-95.

96. Wen LM, Baur LA, Simpson JM, et al. Effectiveness of home based early intervention on children's BMI at age 2: randomised controlled trial. BM7 2012;344:e3732

97. Weeks BK, Beck BR. Twice-weekly, in-school jumping improves lean mass, particularly in adolescent boys. Pediatr Obes 2012;7:196-204.

98. Magnusson KT, Hrafnkelsson H, Sigurgeirsson I, et al. Limited effects of a 2 -year school-based physical activity intervention on body composition and cardiorespiratory fitness in 7-year-old children. Health Educ Res 2012;27:484-94.

99. Brandstetter S, Klenk J, Berg S, et al. Overweight prevention implemented by primary school teachers: a randomised controlled trial. Obes Facts 2012;5:1-11.

100. Escribano J, Luque V, Ferre N, et al. Effect of protein intake and weight gain velocity on body fat mass at 6 months of age: the EU Childhood Obesity Programme. Int 7 Obes (Lond) 2012;36:548-53.

101. Telford RD, Cunningham RB, Fitzgerald R, et al. Physical education, obesity, and academic achievement: a 2-year longitudinal investigation of Australian elementary school children. Am f Public Health 2012;102:368-74.

102. Rush E, Reed P, McLennan S, et al. A school-based obesity control programme: Project Energize. Two-year outcomes. Br 7 Nutr 2012;107:581-7.

103. Thivel D, Isacco L, Lazaar N, et al. Effect of a 6-month school-based physical activity program on body composition and physical fitness in lean and obese schoolchildren. Eur 7 Pediatr 2011;170:1435-43.

104. Nemet D, Geva D, Pantanowitz M, et al. Health promotion intervention in Arab-Israeli kindergarten children. 7 Pediatr Endocrinol Metab 2011;24:1001-7.

105. DeBar LL, Schneider M, Drews KL, et al. Student public commitment in a school-based diabetes prevention project: impact on physical health and health behavior. BMC Public Health 2011;11:711.

106. Bellows LL, Davies PL, Anderson J, et al. Effectiveness of a physical activity intervention for Head Start preschoolers: a randomized intervention study. $\mathrm{Am}$ f Occup Ther 2013;67:28-36.
107. Bonsergent E, Agrinier N, Thilly N, et al. Overweight and obesity prevention for adolescents: a cluster randomized controlled trial in a school setting. Am 7 Prev Med 2013;44:30-9.

108. Brown B, Noonan C, Harris KJ, et al. Developing and piloting the Journey to Native Youth Health program in Northern Plains Indian communities. Diabetes Educ 2013;39:109-18.

109. Campbell KJ, Lioret S, McNaughton SA, et al. A parent-focused intervention to reduce infant obesity risk behaviors: a randomized trial. Pediatrics 2013;131:652-60.

110. Cunha DB, de Souza B, Pereira RA, et al. Effectiveness of a randomized school-based intervention involving families and teachers to prevent excessive weight gain among adolescents in Brazil. PLoS ONE 2013;8:e57498.

111. Daniels LA, Mallan KM, Battistutta D, et al. Evaluation of an intervention to promote protective infant feeding practices to prevent childhood obesity: outcomes of the NOURISH RCT at 14 months of age and 6 months post the first of two intervention modules. Int 7 Obes (Lond) 2012;36:1292-8.

112. De Coen V, De Bourdeaudhuij I, Vereecken C, et al. Effects of a 2-year healthy eating and physical activity intervention for 3-6-year-olds in communities of high and low socio-economic status: the POP (Prevention of Overweight among Preschool and school children) project. Public Health Nutr 2012;15:1737-45.

113. Fitzgibbon ML, Stolley MR, Schiffer L, et al. Family-based hip-hop to health: outcome results. Obesity (Silver Spring) 2013;21:274-83.

114. Madsen K, Thompson H, Adkins A, et al. School-community partnerships: a cluster-randomized trial of an after-school soccer program. 7 AMA Pediatr 2013;167:321-6.

115. Rosário R, Araújo A, Oliveira B, et al. Impact of an intervention through teachers to prevent consumption of low nutrition, energy-dense foods and beverages: a randomized trial. Prev Med 2013;57:20-5.

116. Siegrist M, Lammel C, Haller B, et al. Effects of a physical education program on physical activity, fitness, and health in children: the JuvenTUM project. Scand 7 Med Sci Sports 2013;23:323-30.

117. Yin Z, Moore JB, Johnson MH, et al. The impact of a 3-year after-school obesity prevention program in elementary school children. Child Obes 2012;8:60-70.

Affiliations: McMaster Evidence Review and Synthesis Centre (Peirson, Fitzpatrick-Lewis, Ciliska, Kenny, Usman Ali, Raina), McMaster University, Hamilton, Ont.; Department of Pediatrics (Morrison), McMaster University, Hamilton, Ont.; School of Nursing (Peirson, FitzpatrickLewis, Ciliska), Master University, Hamilton, Ont.; Department of Clinical Epidemiology and Biostatistics (Kenny, Usman Ali, Raina), McMaster University, Hamilton, Ont.

Contributors: Leslea Peirson, Donna Fitzpatrick-Lewis, Katherine Morrison, Donna Ciliska, Meghan Kenny and Parminder Raina were involved in conceptualizing the study, data interpretation and writing and reviewing the manuscript. Leslea Peirson and Donna Fitzpatrick-Lewis were involved in developing the methods, collecting the data and coordinating the project. Muhammad Usman Ali conducted the data analyses and interpretation. All of the authors revised the manuscript, approved the final version submitted for publication and agreed to act as guarantors of the work.

Competing interests: Donna Ciliska and Parminder Raina have received grants from the Canadian Institutes of Health Research. No other competing interests were declared.

Funding: Funding was provided by the CIHR (www.cihr-irsc.gc.ca). The CIHR had no role in the study design, data analysis, interpretation or decision to submit the paper for publication. Parminder Raina holds a Tier 1 Canada Research Chair in Geroscience and the Raymond and Margaret Labarge Chair in Research and Knowledge Application for Optimal Aging.

Acknowledgements: Rachel Warren, Eva Tsakonas and Mary Gauld contributed to the relevance and quality assessment, and data-extraction phases. We are grateful to Maureen Rice for the search and to Sharon Peck-Reid for database management and formatting of the report. Sarah Connor Gorber and Amanda Shane (Scientific Officers, Public Health Agency of Canada) contributed to the original protocol development and review of drafts of the technical report. Similarly, Patricia Parkin, Maria Bacchus, Neil Bell, Paula Brauer and Elizabeth Shaw (members of the Child Obesity Working Group of the Canadian Task Force on Preventive Health Care) provided comments on the protocol and initial analyses.

Disclaimer: The views expressed herein are the opinions of the authors and do not necessarily represent the views of the CIHR or the Canadian Task Force on Preventive Health Care.

Supplemental information: For reviewer comments and the original submission of this manuscript, please see www.cmajopen.ca/content/3/1 /E23/suppl/DC1 